\author{
DEPARTMENT OF THE INTERIOR \\ UNITED STATES GEOLOGICAL SURVEY
}

\title{
LOW FLOW OF STREAMS, HARTFORD NORTH QUADRANGLE, CONNECTICUT
}

By

Donald A. Olin

FOLIO OF THE HARTFORD NORTH QUADRANGLE, CONNECTICUT MAP I-784 N

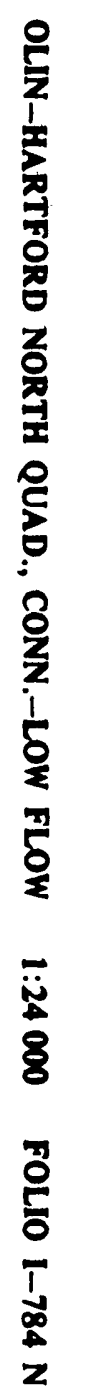

